Indones $J$

\title{
Editorial
}

\section{Improving Quality of Maternal Health Services Through Research and Improvement of Health System in Indonesia}

\section{Dwiana Ocviyanti}

The Indonesian Maternal Mortality Ratio (MMR) in 2015 was estimated at 305 deaths per 100.000 live births. ${ }^{1}$ For years, maternal health programs in Indonesia focused on increasing the number of skilled personnel and promoted facility-based births. ${ }^{2}$ The government and also private sector effort in increasing the number of health care facilities and health care provider especially midwives, doctor and obstetrics and gynecology specialists seems successfully increase the coverage of maternal health care and services in Indonesia. The Basic Health Research (RISKESDAS) in 2018 showed that the coverage of antenatal care by a health care provider in Indonesia is already high $(96.1 \%){ }^{3}$ The coverage of deliveries attended by the health care provider is also high (93.1\%).3 Data from the Ministry of Health shows that during 2010 until 2013 the coverage of antenatal care and deliveries attended by the health care provider is already high and keep increasing, but still, it doesn't reflect in the decreasing of maternal mortality rate. The chief cause of maternal death in Indonesia are still bleeding and hypertension which covers $30.3 \%$ and $27.1 \%$ of maternal death in 2013. Obstructed labour and abortion as the cause of maternal death in 2013 are already rare (nearly 0\%), so also infection (7.3\%), but the percentage of maternal death because of other diseases like heart disease, renal disease, tuberculosis and cancer is increasing, from 32.2\% in 2010 to $40.8 \%$ in 2013.4,5 Some researches had already been done in trying to find the lack of correlation between the coverage of maternal health care programs and services and the maternal mortality in Indonesia. ${ }^{6-11}$ Antenatal care has an integral role in detecting medical problem and/or diseases in pregnant women so also early detection of preeclampsia. Early referral to higherlevel health facilities will save the mother from having complications in late gestational age or during delivery that will result in maternal and neonatal morbidity and mortality. A safe place for delivery means not only the facilities is well equipped for an emergency situation during delivery, but also means that these facilities are in 'reachable" distance from the referral hospital if the mother and/or the baby need emergency referral. An evidence summit intended to gather all relevant evidence related to the cause of maternal and newborn death had been done by the Ministry of Health in collaboration with the Indonesian Academy of Sciences in 2018. The evidence is synthesized and translated into recommendations as a basis for stakeholders to formulate new health policies and follow up to accelerate the reduction of maternal and newborn mortality rates..$^{11}$ Evidence-Informed Policy Making (EIPM) approach was used to achieve the goal. EIPM focused on six topics, namely quality of care, referral system, implementation of national health insurance, local governance contributions, utilization of evidence for decision making and equity of woman. Several methods were used to collect evidence such as systematic reviews, public policy evaluation, practical implementation, lesson learned, political judgment, simple reviews of trusted global literature, and expert consensus. The quality of the evidence determines the level of confidence in recommendations. Policy and further research recommendations were arranged according to topic areas. Evidence-Based Health Policy Approach is still a big challenge in Indonesia, so this evidence summit is expected to increase awareness and culture about the importance of using scientific evidence and stakeholder involvement in formulating public policies. 


\section{REFERENCES}

1. Statistics Indonesia. Profil penduduk Indonesia Hasil SUPAS 2015 [Profile of the people of Indonesia, Supas 2015. Jakarta: 2016.

2. R. Hartwig, R. Sparrow, S. Budiyati et al., "Effects of decentralized health care financing on maternal care in Indonesia," in Institute of Health Policy and Management HEFPA Working Paper.2015.

3. Kementrian Kesehatan: Badan Penelitian dan Pengembangan Kesehatan. Hasil Utama RISKESDAS 2018:200.

4. Info DATIN: Pusat Data dan Informasi Kementrian Kesehatan RI 2014.

5. Profil Kesehatan Indonesia Tahun 2017. Jakarta : Kementerian Kesehatan RI. 2018: 8

6. Mahmood MA, Mufidah I, Scroggs SS, Siddiqui AR, Raheel H, Wibdarminto K, et.al. Root-Cause Analysis of Persistently High Maternal Mortality in a Rural District of Indonesia: Role of Clinical Care Quality and Health Services Organizational Factors. Bio Med Research Int. 2018:1.

7. Afifah T, Tejayanti T, Saptarini I, Rizkianti A, Usman Y, Senewe FP, et.al. Maternal Death In Indonesia: Follow-Up Study of The 2010 Indonesia Population Census. 14.

8. Kementrian Kesehatan Republik Indonesia, UNFPA 2012. Disparity of Access and Quality; Review of Maternal Mortality in Five region of Indonesia. 2012:42.

9. Girum T, Wasie A. Correlates of maternal mortality in developing countries: an ecological study in 82 countries. Maternal Health, Neonatol Perinatol. 2017; 3:19.

10. Ahmed S, Fullerton J. Challenges of reducing maternal and neonatal mortality in Indonesia: Ways forward. Int J Gynecol Obstet. 2019; 144 (Suppl. 1): 1-3.

11. Consensus Report 2018. Evidence Summit on Reducing Maternal and Neonatal Mortality in Indonesia. Indones Academy Scien 2018: 72. 